CLINICAL STUDY

\title{
Diagnostic value of a ghrelin test for the diagnosis of GH deficiency after subarachnoid hemorrhage
}

\author{
K Blijdorp $^{1, *}$, L Khajeh ${ }^{2, *}$, G M Ribbers ${ }^{3,4}$, E M Sneekes ${ }^{3}$, M H Heijenbrok-Kal ${ }^{3,4}$, H J G van den Berg-Emons ${ }^{3}$, \\ A J van der Lely ${ }^{1}$, F van Kooten ${ }^{2, \dagger}$ and S J C M M Neggers ${ }^{1, \dagger}$ \\ Departments of ${ }^{1}$ Medicine - Endocrinology, ${ }^{2}$ Neurology and ${ }^{3}$ Rehabilitation Medicine, Erasmus University Medical Center Rotterdam, \\ PO Box 2040, 3000 CA Rotterdam, The Netherlands and ${ }^{4}$ Rijndam Rehabilitation Center, Rotterdam, The Netherlands \\ (Correspondence should be addressed to L Khajeh; Email: l.khajeh@erasmusmc.nl) \\ *(K Blijdorp and L Khajeh are joint first authors) \\ ${ }^{\dagger}$ (F van Kooten and SJCMM Neggers are joint last authors)
}

\begin{abstract}
Objective: To determine the diagnostic value of a ghrelin test in the diagnosis of GH deficiency (GHD) shortly after aneurysmal subarachnoid hemorrhage (SAH).

Design: Prospective single-center observational cohort study.

Methods: A ghrelin test was assessed after the acute phase of SAH and a GH-releasing hormone (GHRH)-arginine test 6 months post SAH. Primary outcome was the diagnostic value of a ghrelin test compared with the GHRH-arginine test in the diagnosis of GHD. The secondary outcome was to assess the safety of the ghrelin test, including patients' comfort, adverse events, and idiosyncratic reactions. Results: Forty-three survivors of SAH were included (15 males, 35\%, mean age 56.6 11.7 ). Six out of 43 (14\%) SAH survivors were diagnosed with GHD by GHRH-arginine test. In GHD subjects, median GH peak during ghrelin test was significantly lower than that of non-GHD subjects (5.4 vs 16.6, $P=0.002)$. Receiver operating characteristics analysis showed an area under the curve of 0.869 . A cutoff limit of a GH peak of $15 \mu \mathrm{g} / \mathrm{l}$ corresponded with a sensitivity of $100 \%$ and a false-positive rate of $40 \%$. No adverse events or idiosyncratic reactions were observed in subjects undergoing a ghrelin test, except for one subject who reported flushing shortly after ghrelin infusion.

Conclusion: Owing to its convenience, validity, and safety, the ghrelin test might be a valuable GH provocative test, especially in the early phase of SAH.

European Journal of Endocrinology 169 497-502
\end{abstract}

\section{Introduction}

The incidence of spontaneous subarachnoid hemorrhage (SAH) in The Netherlands varies between $5.7 / 100000$ subjects per year for men and 9.9/100 000 subjects per year for women. About 50\% of SAH patients do not survive $(1,2)$. Those who do survive SAH have high rates of functional limitations that could lead to impaired quality of life, fatigue, decreased mobility, and loss of motivation. These symptoms could be caused by growth hormone deficiency (GHD) (3).

The prevalence of hypopituitarism after SAH varies between 0 and $55 \%$, with GHD in $0-29 \%$ being the largest deficit among all SAH patients $(3,4,5,6,7,8,9$, $10,11,12)$. This neuro-endocrine dysfunction may result from the hypothalamic/pituitary system being damaged as a result of post hemorrhagic complications, e.g. local tissue pressure, toxic effects of the extravasated blood, ischemia, hydrocephalus, or local destruction during cerebral surgery.

(C) 2013 The authors

DOI: 10.1530/EJE-13-0436

Online version via www.eje-online.org
GHD is diagnosed by a dynamic stimulatory test, as standard serum insulin-like growth factor 1 (IGF1) tests cannot discriminate between sufficient and insufficient GH secretion (13). Currently, the gold standard for the diagnosis of GHD is the insulin tolerance test. As this test is contra-indicated in the elderly and in patients with ischemic heart disease and seizures, it is regularly replaced by the GH-releasing hormone (GHRH)arginine test, which is well-validated in adults (13). However, as both tests are burdensome and limited by side effects such as vasodilatation and paresthesia (14), they are not useful in the early phase after SAH where these side effects may be confused with the complications of SAH such as delayed cerebral ischemia which need proper treatment.

It might be possible to diagnose GHD occurring shortly after SAH by combining early hormonal screening with GH stimulation testing. By its binding to the GH secretagogue receptor-type 1a (GHSR-1a), ghrelin has a strong GH-releasing activity, and can be used as a diagnostic test. A ghrelin test is not limited by 
side effects and it has the advantage of also stimulating adrenocorticotrophin (ACTH) (15). As there is little data describing the use of ghrelin as a GH-stimulating diagnostic test, the aim was to determine the diagnostic value of a ghrelin test shortly after SAH to identify subjects with GHD and to define the cutoff limit of the $\mathrm{GH}$ peak below which GHD is confirmed.

\section{Subjects and methods}

\section{Study design}

This study was part of the HIPSS (hypopituitarism in patients after subarachnoid hemorrhage study), a prospective single-center observational cohort study at the Erasmus University Medical Center Rotterdam. It was approved by the Local Medical Ethical Committee (METC). All patients gave written informed consent. Adverse events were registered and reported to the Central Committee for human scientific research (CCMO).

\section{Subjects}

Included in this study were all patients with aneurysmal $\mathrm{SAH}$, aged $\geq 18$ years. All patients included in this study were treated for SAH before inclusion. They were dismissed from the intensive care unit (ICU) and admitted to the Department of Neurology of the Erasmus Medical Center between June 2009 and June 2012. We excluded patients with any hypothalamic/ pituitary disease, former cranial irradiation, prior significant head trauma, or any other medical condition or laboratory abnormality that may have interfered with the outcome of the study.

\section{Clinical definitions and outcome measures}

The primary outcome was to compare the ghrelin test with the GHRH-arginine test in terms of their value for the diagnosis of GHD. The secondary outcome was to assess the safety of the ghrelin test, including patients' comfort, adverse events, and idiosyncratic reactions.

The diagnosis of SAH was confirmed by computerized tomography (CT) or lumbar puncture. Localization of the aneurysm was determined by CT angiography or a digital subtraction angiography. We defined GH deficiency (GHD) as an insufficient GH response to a GHRH-arginine test, assessed at 6 months after SAH. We used the following cutoff limits to define GHD for the GHRH-arginine test: for subjects with a BMI

Table 1 Baseline characteristics and results of dynamic tests of included and excluded survivors.

\begin{tabular}{|c|c|c|}
\hline & \multicolumn{2}{|c|}{ Values are expressed as $n(\%)$ of subjects ${ }^{a}$} \\
\hline & $\begin{array}{l}\text { SAH patients with ghrelin test and } \\
\text { GHRH-arginine test }(n=43)\end{array}$ & $\begin{array}{l}\text { Excluded SAH patients in the } \\
\text { current study }(n=41)\end{array}$ \\
\hline Sex (male) & $15(35)$ & $9(22)$ \\
\hline Age (years) & $56.6 \pm 11.7$ & $56.3 \pm 11.8$ \\
\hline $\mathrm{BMI}$ & $25.3 \pm 3.1$ & $24.8 \pm 4.2$ \\
\hline$<25 \mathrm{~kg} / \mathrm{m}^{2}$ & $22(51)$ & $23(56)$ \\
\hline $25-30 \mathrm{~kg} / \mathrm{m}^{2}$ & $17(40)$ & $12(29)$ \\
\hline$>30 \mathrm{~kg} / \mathrm{m}^{2}$ & $4(9)$ & $6(15)$ \\
\hline \multicolumn{3}{|l|}{ WFNS } \\
\hline I & $17(40)$ & $21(51)$ \\
\hline II & $15(35)$ & $10(24)$ \\
\hline III & $3(7)$ & 0 \\
\hline IV & $5(11)$ & $6(15)$ \\
\hline V & $3(7)$ & $4(10)$ \\
\hline \multicolumn{3}{|l|}{ Location of aneurysm } \\
\hline Anterior circulation & $24(56)$ & $25(61)$ \\
\hline Posterior circulation & $19(44)$ & $16(39)$ \\
\hline \multicolumn{3}{|l|}{ Aneurysm treatment } \\
\hline Endovascular treatment & $37(86)$ & $29(71)$ \\
\hline Clipping & $6(14)$ & $11(27)$ \\
\hline None & 0 & $1(2)$ \\
\hline Hydrocephalus & $19(44)$ & $13(32)$ \\
\hline Delayed cerebral ischemia & $3(7)$ & $5(12)$ \\
\hline GH peak ghrelin test $(\mu \mathrm{g} / \mathrm{l})$ & $15.3(1.6-117)^{\mathrm{b}}$ & $n=15,19.3(8.2-35.4)^{\mathrm{b}}$ \\
\hline $\mathrm{GH}$ response $<5 \mu \mathrm{g} / \mathrm{l}$ & $6(14)$ & 0 \\
\hline Baseline IGF1 SDS (95\% Cl) & $-0.06(-2.1 ; 1.94)^{\mathrm{C}}$ & \\
\hline GH peak GHRH-arginine test $(\mu \mathrm{g} / \mathrm{l})$ & $18.1(2.4-104)^{\mathrm{b}}$ & $n=10,23.2(4.6-114.0)^{b}$ \\
\hline Insufficient GH response & $6(14)$ & $2(5)$ \\
\hline 6-month IGF1 SDS $(95 \% \mathrm{Cl})$ & $-0.7(-2.56 ; 1.16)^{\mathrm{c}}$ & \\
\hline
\end{tabular}

$\mathrm{GH}$, growth hormone; GHRH, GH-releasing hormone; SAH, subarachnoid hemorrhage; WFNS, World Federation of Neurologic Surgeons grading system for subarachnoid haemorrhage scale.

a Unless otherwise specified.

${ }^{\mathrm{b}}$ Expressed as median (range)

${ }^{\circ}$ Expressed as mean $(95 \% \mathrm{Cl})$ 
$<25 \mathrm{~kg} / \mathrm{m}^{2}$, a peak $\mathrm{GH}<11 \mu \mathrm{g} / \mathrm{l}$; for subjects with a BMI between 25 and $30 \mathrm{~kg} / \mathrm{m}^{2}$, a peak $\mathrm{GH}<8 \mu \mathrm{g} / \mathrm{l}$; and for subjects with a BMI $>30 \mathrm{~kg} / \mathrm{m}^{2}$, a peak GH $<4 \mu \mathrm{g} / \mathrm{l}(13)$.

To rule out interference of other hormonal deficiencies, we simultaneously measured basal hormone levels including cortisol, free thyroxin, thyroid-stimulating hormone, prolactin (PRL), IGF1, and IGF binding protein 3, in men and women; testosterone in men; and estradiol, follicle-stimulating hormone, and luteinizing hormone in women. IGF1 was assessed by immulite 2000 (DPC Biermann GmbH/Siemens, Fernwald, Germany), a solid-phase, enzyme-labeled chemiluminescent immunometric assay, with an intra-assay variability of $2-5 \%$, and an inter-assay variability of 3-7\% (16), we calculated IGF1 mean SDS (17). IGFSDS are depicted in Table 1.

\section{Acute phase}

A ghrelin test was assessed in a fasting patient at rest, during admission after SAH. BMI was calculated from height and body weight (18). At baseline, we measured $\mathrm{GH}$ and cortisol, and then infused $1 \mu \mathrm{g} / \mathrm{kg}$ body weight acylated ghrelin. $\mathrm{GH}$ and cortisol were measured after 30 and 60 min. A recent study has shown that individual peak $\mathrm{GH}$ response to ghrelin occurred in all subjects between 15 and 45 min with a curve maximum at $30 \mathrm{~min}$ after ghrelin test, in GHD and non-GHD patients (19).

\section{Six months post-SAH}

A GHRH-arginine test was assessed at the research unit 6 months after SAH. GH was measured, followed by infusion of $1 \mu \mathrm{g} / \mathrm{kg}$ body weight GHRH and $0.5 \mathrm{mg} / \mathrm{kg}$ arginine within $30 \mathrm{~min}$. GH was assessed every 5-15 min.

\section{Statistical analysis}

Data were expressed as mean \pm s.D. for normal distributed variables or as median (ranges) for nonnormative variables. To evaluate differences in GH peak between GHD and non-GHD subject, Mann-Whitney $U$ test was assessed. To determine the value of applying a ghrelin test shortly after SAH to identify subjects with GHD, the sensitivity, specificity, and positive and negative predictive values were calculated using receiver operating characteristics (ROC) analysis. The reference test for the detection of GHD is the GHRH-arginine test. In addition, the likelihood ratios of a positive ghrelin test and of a negative ghrelin test were calculated. All statistical analyses were performed with SPSS version 20.0 (SPSS, Inc., Chicago, IL, USA).

\section{Results}

\section{Patients}

Out of 241 patients admitted to the ICU with the diagnosis of SAH, 193 survived. Fifty-one patients did not fulfill the inclusion criteria, 38 refused to participate, and 20 patients were discharged before the inclusion was fulfilled. Eventually, 84 patients were included in the HIPSS study (Fig. 1). Fifteen patients had a ghrelin test and no GHRHarginine test. They found the endurance of the dynamic tests too strenuous. At the start of the study, ghrelin test was not at our disposal; so ten patients only had a GHRHarginine test but no ghrelin test, and 16 patients did not give us permission to perform the dynamic tests.

In 43 patients, both the ghrelin test and the GHRHarginine test were assessed and therefore the data of 43 patients were analyzed in the current study. Patient characteristics are outlined in Table 1. Median time between occurrence of SAH and ghrelin test was 18 days. Patient characteristics of excluded and included subjects did not differ significantly (sex: male, 9/41 (22\%) vs $15 / 43$ (35\%), $P=0.142$; mean age, 56.3 vs 56.6 years, $P=0.912$ ).

\section{Outcome}

Six out of 43 (14\%) SAH survivors were diagnosed with GHD by the GHRH-arginine test. The median GH peak

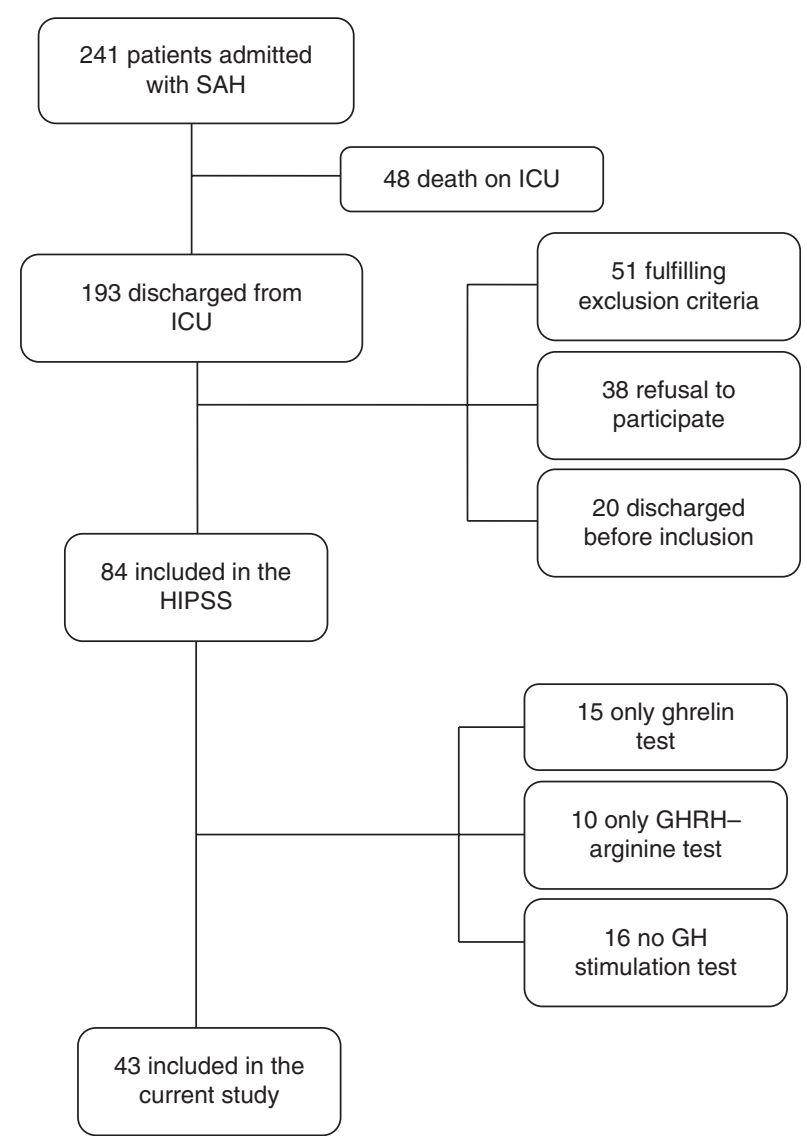

Figure 1 Inclusion criteria for subjects. SAH, subarachnoid hemorrhage; ICU, intensive care unit; $\mathrm{GH}$, growth hormone; $\mathrm{GHRH}$, GH-releasing hormone; HIPSS, hypopituitarism in patients after subarachnoid hemorrhage study. 
of GHD subjects was $5.4 \mu \mathrm{g} / \mathrm{l}$ during the ghrelin test and $6.2 \mu \mathrm{g} / \mathrm{l}$ during the GHRH-arginine test (Fig. 2). In GHD subjects, median GH peak during ghrelin test was significantly lower than that of non-GHD subjects (5.4 (range 1.6-14.6) vs 16.6 (4.1-117), $P=0.002$ ). We observed a low cortisol level in one patient $(2 \%)$ during ghrelin testing. This subject who was re-tested using the synacthen-test did not reveal a secondary hypocortisolaemia. Three male patients with GHD also had a hypogonadotropic hypogonadism. Another nine patients in this study had hypogonadotropic hypogonadism after 6 months.

ROC analysis showed an area under the curve of 0.869 . Table 2 gives an overview of sensitivity, specificity, positive predictive value, and negative predictive value for different cutoff limits of the GH peak during a ghrelin test. A sensitivity of $100 \%$, which is needed to diagnose every GHD subject, gives a falsepositive rate of $40 \%$ (1-specificity), belonging to a cutoff of $15 \mu \mathrm{g} / \mathrm{l}$ (Table 2). A cutoff of $11.4 \mu \mathrm{g} / \mathrm{l}$ gives the optimal combination of the highest sensitivity $(83 \%)$ and the highest specificity (73\%).

\section{Adverse events/safety measures}

Only one subject reported an adverse effect, i.e. flushing starting shortly after ghrelin infusion, which lasted for 30 min. During this period, we monitored heart

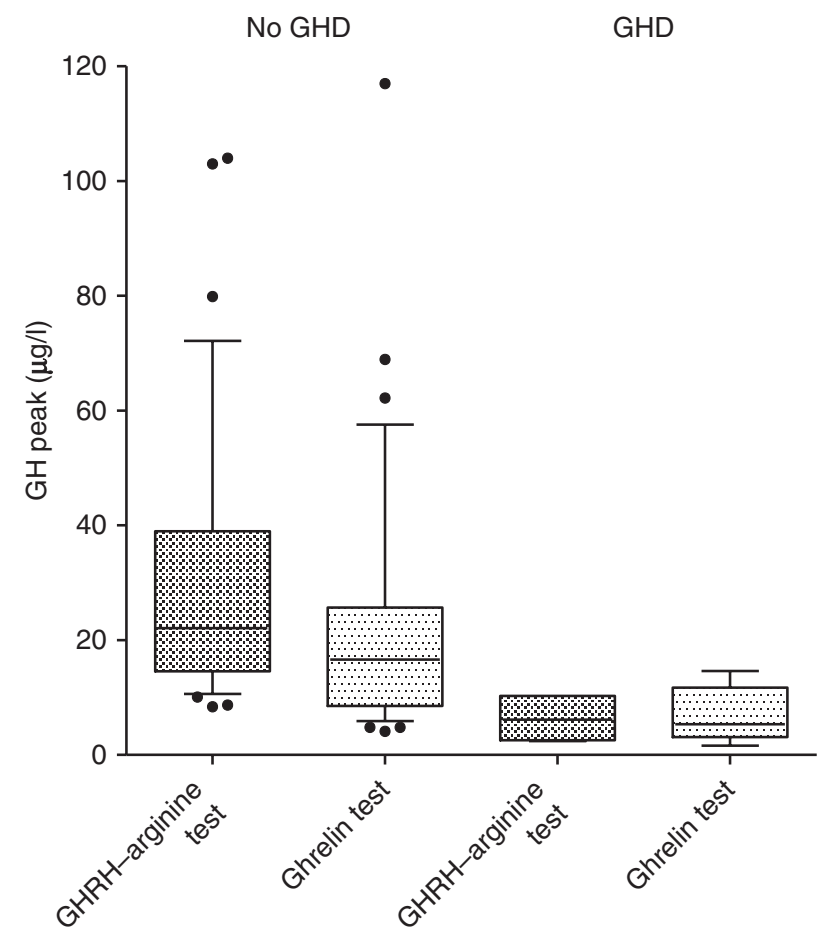

Figure $2 \mathrm{GH}$ peak in $\mathrm{GH}$-deficient subjects vs non-GH-deficient subjects. GH, growth hormone; GHRH, GH-releasing hormone.
Table 2 Summary statistics for various GH cutoff values for the ghrelin test predicting GH deficiency.

\begin{tabular}{lcccr}
\hline $\begin{array}{l}\text { GH cutoff for } \\
\text { ghrelin test }\end{array}$ & $\begin{array}{c}\text { Sensitivity } \\
(\%)\end{array}$ & $\begin{array}{c}\text { Specificity } \\
(\%)\end{array}$ & $\begin{array}{c}\text { PPV } \\
(\%)\end{array}$ & $\begin{array}{r}\text { NPV } \\
(\%)\end{array}$ \\
\hline 2.6 & 17 & 100 & 100 & 88 \\
3.9 & 33 & 100 & 100 & 90 \\
4.8 & 50 & 97 & 75 & 92 \\
6.1 & 67 & 92 & 57 & 94 \\
11.4 & 83 & 73 & 33 & 96 \\
15.0 & 100 & 60 & 29 & 100 \\
20.0 & 100 & 38 & 21 & 100 \\
30.4 & 100 & 16 & 16 & 100 \\
\hline
\end{tabular}

$\mathrm{GH}$, growth hormone; PPV, positive predictive value; NPV, negative predictive value.

frequency and blood pressure, which remained stable. No adverse events or idiosyncratic reactions were reported by or observed in the other subjects undergoing a ghrelin test.

\section{Discussion}

Ghrelin testing is a safe and valid alternative in the diagnosis of GHD shortly after SAH. Other current available $\mathrm{GH}$ provocative tests might be burdensome and their use is limited in SAH survivors because of their possible side effects.

Ghrelin, a 28-amino-acid peptide hormone, is predominantly produced by the stomach, stimulates food intake and a positive energy balance, and plays an important role in fat metabolism (20). Besides, ghrelin has strong GH-releasing activity by binding to the GHSR-1a. Apart from stimulating GH secretion, ghrelin exhibits hypothalamic activities resulting in the stimulation of PRL and ACTH secretion (20). Previous studies described the use of ghrelin as a GH stimulation test, when combined with GHRH, illustrating a strong and potent GH-releasing activity due to the synergistic effects of ghrelin and GHRH $(21,22,23,24)$. In addition, administration of ghrelin alone illustrated a GH release with a clear dose-response curve in normal subjects $(22,25)$. In GHD subjects, GH response was significantly lower than that in normal subjects, illustrating the value of a ghrelin test in diagnosing GHD (24). The use of GH-releasing peptide 6, which is an artificial hexapeptide activating the GHSRla, in combination with GHRH, has been described as a potent GH-provocative test in several studies investigating pituitary dysfunction after traumatic brain injury $(26,27,28)$. In the current study, a ghrelin test was assessed shortly after SAH and illustrated a significantly lower GH peak in GHD subjects compared with nonGHD subjects. ROC analysis showed a high accuracy of the ghrelin test when compared with GHRH-arginine test. The GHRH-arginine test, however, is inconvenient in SAH patients because of its known side effects such as vasodilatation and paresthesia (14). A more safe and 
patient friendly test, like a ghrelin test, would be preferred, especially in disabled patients who are critically ill. Another known side effect of GHRH administration is transient facial flushing, which occurs in $25 \%$ of the patients (14). In our view, this side effect might be related to fluctuating blood pressure, which is also undesirable in patients in the early phase after $\mathrm{SAH}$.

In a recent paper published by Gasco et al. (19), ghrelin test proved to be a valid diagnostic test for GHD in adults with reliable cutoff limits in lean and overweight patients. Furthermore, they concluded that obesity has an impact on the GH response to ghrelin, lowering the predictive value of the test in these patients, so caution must be taken when it comes to interpreting ghrelins test in obese patients. However, obesity has an impact on almost all dynamic GHD tests (29). They also described that facial flushing occurred in a smaller group of patients after ghrelin test compared with GHRH-arginine test. Other adverse events of ghrelin administration have not been described so far except for patients receiving more than $250 \mu \mathrm{g}$ of ghrelin, who reported transient hyperhydrosis $(22,25)$.

Beside its convenience, the ghrelin test would be preferred above the GHRH-arginine test because, by stimulating ACTH release, adrenal function could be evaluated. The prevalence of adrenocorticotropic deficiency following SAH varies from 0 to $40 \%(6,7,8,12)$ and could lead to life-threatening conditions if untreated. This elucidates added value of the ghrelin test as it can be used to detect a secondary adrenocorticotropic deficiency early after SAH. However, as the ACTH-releasing activity is less potent, higher ghrelin doses may be needed in order to discriminate between sufficient and insufficient cortisol response (24). Therefore, the evaluation of adrenal function by ghrelin testing should be elucidated in further studies.

We observed that a second confirmatory test was needed to confirm true GHD in patients who had low GH response to the ghrelin test. A recent study by Gardner et al. (30) also concluded that real GHD in SAH patients has to be confirmed by two different stimulation tests and by the application of BMI specific cutoffs. Based on these findings, we recommend the usage of two different stimulation tests for the confirmation of true isolated GHD.

The limitation of this study was that cutoff limits for the ghrelin test could not be defined, as only six patients had been diagnosed with GHD. Fortunately, the cut off values for ghrelin test have been recently published by a different group of investigators (19).

Secondly, the time between GH stimulation tests could be an important confounder because hypopituitarism in the acute phase has been described to resolve in the post-acute phase $(11,31)$. This might be caused by the SAH or SAH's related complications. Furthermore, the fact that the subjects are critically ill could also have a significant impact on the results of the ghrelin test. However, some studies have shown that in contrast to both hypogonadism and hypocortisolism that can normalize during follow-up, GHD prevalence remained stable until 1 year after SAH $(4,32)$. Ideally, multiple GHD tests in this early phase could exclude these possible confounders; however, it is not feasible to perform multiple tests in critically ill SAH patients.

In conclusion, the ghrelin test discriminated between GHD and non-GHD survivors of SAH and displayed a high accuracy compared with the GHRH-arginine test. Owing to its convenience, validity, and safety, the ghrelin test is a novel $\mathrm{GH}$ provocative test that can be used as a screening tool for the prediction of late GHD in SAH patients.

\section{Declaration of interest}

The authors declare that there is no conflict of interest that could be perceived as prejudicing the impartiality of the research reported.

\section{Funding}

This study was financially supported by an unrestricted grant of Pfizer and by the Dutch Brain Foundation.

\section{References}

1 Rinkel GJ \& Algra A. Long term outcomes of patients with aneurysmal subarachnoid haemorrhage. Lancet Neurology 2011 $10349-356$.

2 Nieuwkamp DJ, Vaartjes I, Algra A, Rinkel GJ \& Bots ML. Risk of cardiovascular events and death in the life after aneurysmal subarachnoid haemorrhage: a nationwide study. International Journal of Stroke 2013. In press. (doi:10.1111/j.1747-4949.2012. 00875.x)

3 Kreitschmann-Andermahr I, Hoff C, Saller B, Niggemeier S, Pruemper S, Hutter BO, Rohde V, Gressner A, Matern S \& Gilsbach JM. Prevalence of pituitary deficiency in patients after aneurysmal subarachnoid hemorrhage. Journal of Clinical Endocrinology and Metabolism 200489 4986-4992. (doi:10.1210/ jc.2004-0146)

4 Tanriverdi F, Dagli AT, Karaca Z, Unluhizarci K, Selcuklu A, Casanueva FF \& Kelestimur F. High risk of pituitary dysfunction due to aneurysmal subarachnoid haemorrhage: a prospective investigation of anterior pituitary function in the acute phase and 12 months after the event. Clinical Endocrinology 200767 931-937. (doi:10.1111/j.1365-2265.2007.02989.x)

5 Lammert A, Bode H, Hammes HP, Birck R, Fatar M, Zohsel K, Braun J, Schmieder K, Diepers M, Schubert GA et al. Neuroendocrine and neuropsychological outcome after aneurysmal subarachnoid hemorrhage (aSAH): a prospective cohort study. Experimental and Clinical Endocrinology \& Diabetes 2011119 111-116. (doi:10.1055/s-0030-1262815)

6 Kreitschmann-Andermahr I, Poll EM, Reineke A, Langejurgen Y, Yagmur E, Gilsbach JM \& Saller B. Diagnosing neuroendocrine dysfunction in patients after aneurysmal subarachnoid hemorrhage in clinical practice - does basal hormone screening make sense? Experimental and Clinical Endocrinology $\mathcal{E}$ Diabetes 2008 116 276-281. (doi:10.1055/s-2007-1004552)

7 Klose M, Brennum J, Poulsgaard L, Kosteljanetz M, Wagner A \& Feldt-Rasmussen U. Hypopituitarism is uncommon after aneurysmal subarachnoid haemorrhage. Clinical Endocrinology 201073 95-101. (doi:10.1111/j.1365-2265.2010.03791.x)

8 Jovanovic V, Pekic S, Stojanovic M, Tasic G, Djurovic B, Soldatovic I, Doknic M, Miljic D, Djurovic M, Medic-Stojanoska M et al. Neuroendocrine dysfunction in patients recovering from subarachnoid hemorrhage. Hormones 20109 235-244. 
9 Dimopoulou I, Kouyialis AT, Tzanella M, Armaganidis A, Thalassinos N, Sakas DE \& Tsagarakis S. High incidence of neuroendocrine dysfunction in long-term survivors of aneurysmal subarachnoid hemorrhage. Stroke $2004352884-2889$. (doi:10.1161/01.STR.0000147716.45571.45)

10 Brandt L, Saveland H, Valdemarsson S, Sjoholm H \& Reinstrup P. Fatigue after aneurysmal subarachnoid hemorrhage evaluated by pituitary function and 3D-CBF. Acta Neurologica Scandinavica 2004109 91-96. (doi:10.1046/j.0001-6314.2003.00189.x)

11 Aimaretti G, Ambrosio MR, Di Somma C, Gasperi M, Cannavo S, Scaroni C, Fusco A, Del Monte P, De Menis E, Faustini-Fustini M et al. Residual pituitary function after brain injury-induced hypopituitarism: a prospective 12-month study. Journal of Clinical Endocrinology and Metabolism 200590 6085-6092. (doi:10.1210/jc.2005-0504)

12 Aimaretti G, Ambrosio MR, Di Somma C, Fusco A, Cannavo S, Gasperi M, Scaroni C, De Marinis L, Benvenga S, degli Uberti EC et al. Traumatic brain injury and subarachnoid haemorrhage are conditions at high risk for hypopituitarism: screening study at 3 months after the brain injury. Clinical Endocrinology 200461 320-326. (doi:10.1111/j.1365-2265.2004.02094.x)

13 Ho KK \& Participants GHDCW. Consensus guidelines for the diagnosis and treatment of adults with GH deficiency II: a statement of the GH Research Society in association with the European Society for Pediatric Endocrinology, Lawson Wilkins Society, European Society of Endocrinology, Japan Endocrine Society, and Endocrine Society of Australia. European Journal of Endocrinology 2007157 695-700. (doi:10.1530/EJE-07-0631)

14 Biller BM, Samuels MH, Zagar A, Cook DM, Arafah BM, Bonert V, Stavrou S, Kleinberg DL, Chipman JJ \& Hartman ML. Sensitivity and specificity of six tests for the diagnosis of adult GH deficiency. Journal of Clinical Endocrinology and Metabolism $2002 \mathbf{8 7}$ 2067-2079. (doi:10.1210/jc.87.5.2067)

15 Ghigo E, Arvat E, Ramunni J, Colao A, Gianotti L, Deghenghi R, Lombardi G \& Camanni F. Adrenocorticotropin- and cortisolreleasing effect of hexarelin, a synthetic growth hormonereleasing peptide, in normal subjects and patients with Cushing's syndrome. Journal of Clinical Endocrinology and Metabolism 1997 82 2439-2444. (doi:10.1210/jc.82.8.2439)

16 Health BNIo. NIohN, National Heart, Lung, and Blood Institute (NHBLI). The practical guide: identification, evaluation, and treatment of overweight and obesity in adults. NIH publications 2000 00-4084.

17 Elmlinger MW, Kuhnel W, Weber MM \& Ranke MB. Reference ranges for two automated chemiluminescent assays for serum insulin-like growth factor I (IGF-I) and IGF-binding protein 3 (IGFBP-3). Clinical Chemistry and Laboratory Medicine $2004 \mathbf{4 2}$ 654-664. (doi:10.1515/CCLM.2004.112)

18 Khosla $\mathrm{T} \&$ Lowe CR. Indices of obesity derived from body weight and height. British Journal of Preventive E Social Medicine 196721 122-128.

19 Gasco V, Beccuti G, Baldini C, Prencipe N, Di Giacomo S, Berton A, Guaraldi F, Tabaro I, Maccario M, Ghigo E et al. Acylated ghrelin as a provocative test for the diagnosis of GH deficiency in adults. European Journal of Endocrinology 2013168 23-30. (doi:10.1530/ EJE-12-0584)

20 van der Lely AJ, Tschop M, Heiman ML \& Ghigo E. Biological, physiological, pathophysiological, and pharmacological aspects of ghrelin. Endocrine Reviews 200425 426-457. (doi:10.1210/ er.2002-0029)

21 Leal-Cerro A, Garcia E, Astorga R, Casanueva FF \& Dieguez C. Growth hormone $(\mathrm{GH})$ responses to the combined administration of GH-releasing hormone plus GH-releasing peptide 6 in adults with GH deficiency. European Journal of Endocrinology 1995132 712-715. (doi:10.1530/eje.0.1320712)
22 Hataya Y, Akamizu T, Takaya K, Kanamoto N, Ariyasu H, Saijo M, Moriyama K, Shimatsu A, Kojima M, Kangawa K et al. A low dose of ghrelin stimulates growth hormone $(\mathrm{GH})$ release synergistically with GH-releasing hormone in humans. Journal of Clinical Endocrinology and Metabolism 200186 4552. (doi:10.1210/jc.86. 9.4552)

23 Ghigo E, Arvat E, Aimaretti G, Broglio F, Giordano R \& Camanni F. Diagnostic and therapeutic uses of growth hormone-releasing substances in adult and elderly subjects. Baillière's Clinical Endocrinology and Metabolism 199812 341-358. (doi:10.1016/ S0950-351X(98)80027-X)

24 Aimaretti G, Baffoni C, Broglio F, Janssen JA, Corneli G, Deghenghi R, van der Lely AJ, Ghigo E \& Arvat E. Endocrine responses to ghrelin in adult patients with isolated childhoodonset growth hormone deficiency. Clinical Endocrinology 200256 765-771. (doi:10.1046/j.1365-2265.2002.01547.x)

25 Peino R, Baldelli R, Rodriguez-Garcia J, Rodriguez-Segade S, Kojima M, Kangawa K, Arvat E, Ghigo E, Dieguez C \& Casanueva FF. Ghrelin-induced growth hormone secretion in humans. European Journal of Endocrinology 2000143 R11-R14. (doi:10.1530/eje.0.143R011)

26 Tanriverdi F, Senyurek H, Unluhizarci K, Selcuklu A, Casanueva FF \& Kelestimur F. High risk of hypopituitarism after traumatic brain injury: a prospective investigation of anterior pituitary function in the acute phase and 12 months after trauma. Journal of Clinical Endocrinology and Metabolism 200691 2105-2111. (doi:10.1210/jc.2005-2476)

27 Popovic V, Pekic S, Pavlovic D, Maric N, Jasovic-Gasic M, Djurovic B, Medic Stojanoska M, Zivkovic V, Stojanovic M, Doknic $\mathrm{M}$ et al. Hypopituitarism as a consequence of traumatic brain injury (TBI) and its possible relation with cognitive disabilities and mental distress. Journal of Endocrinological Investigation 2004 27 1048-1054.

28 Leal-Cerro A, Flores JM, Rincon M, Murillo F, Pujol M, GarciaPesquera F, Dieguez C \& Casanueva FF. Prevalence of hypopituitarism and growth hormone deficiency in adults long-term after severe traumatic brain injury. Clinical Endocrinology 200562 525-532. (doi:10.1111/j.1365-2265.2005.02250.x)

29 Ghigo E, Aimaretti G \& Corneli G. Diagnosis of adult GH deficiency. Growth Hormone E IGF Research 200818 1-16. (doi:10.1016/ j.ghir.2007.07.004)

30 Gardner CJ, Javadpour M, Stoneley C, Purthuran M, Biswas S, Daousi C, MacFarlane IA \& Cuthbertson DJ. Low prevalence of hypopituitarism after subarachnoid haemorrhage using confirmatory testing and with BMI-specific GH cut-off levels. European Journal of Endocrinology $2013 \mathbf{1 6 8} 473-481$. (doi:10.1530/ EJE-12-0849)

31 Agha A, Phillips J, O'Kelly P, Tormey W \& Thompson CJ. The natural history of post-traumatic hypopituitarism: implications for assessment and treatment. American Journal of Medicine 2005 118 1416. (doi:10.1016/j.amjmed.2005.02.042)

32 Schneider HJ, Schneider M, Saller B, Petersenn S, Uhr M, Husemann B, von Rosen F \& Stalla GK. Prevalence of anterior pituitary insufficiency 3 and 12 months after traumatic brain injury. European Journal of Endocrinology 2006154 259-265. (doi:10.1530/eje.1.02071)

Received 22 May 2013

Revised version received 17 July 2013

Accepted 31 July 2013 